\title{
Sistem Pendukung Keputusan Menggunakan Metode Analytic Hierarchy Process (AHP) Pemilihan Metode Pembelajaran untuk Mata Kuliah Praktikum yang Berbasiskan Bahasa Pemrograman Komputer
}

\author{
Thomson Mary ${ }^{1}$, Yusran $^{2}$ \\ Program Studi Pendidikan Informatika, STKIP PGRI Sumatera Barat \\ Email: thomsonmary1980@gmail.com
}

http://dx.doi.org/10.22202/jei.2014.v1i1.1432

\begin{abstract}
ABSTRAK
Latar belakang penelitian ini adalah dalam menemukan metode pembelajaran berbasis komputer yang khusus digunakan untuk mata kuliah praktikum komputer terutama yang berbasiskan bahasa pemrograman komputer. Hal tersebut dilatar belakangi kesulitan Mahasiswa dalam memahami mata kuliah pratikum yang berbasiskan bahasa pemrograman komputer. Teori dan modul praktikum yang telah diberikan, melalui empiris masih belum cukup dalam menunjang keberhasilan Mahasiswa memahaminya, hal ini bukan berarti mata kuliah praktikum terlalu sulit untuk dipahami, namun bisa saja karena berbagai aspek seperti : kurangnya minat dalam membaca, memahami dan mempraktekan modul, terlalu takut dengan matematika yang ada dalam bahasa pemrograman komputer, ataupun dari metode-metode pembelajaran yang digunakan. Untuk itulah penelitian ini memfokuskan kepada metode pembelajaran yang terbaik dan efektif untuk mendapatkan pemahaman terhadap perkuliahan praktikum yang berbasiskan bahasa pemrograman komputer. Dalam memilih metode pembelajaran terbaik, terlebih dahulu merangkum kriteria-kriteria serta alternatif-alternatif metode pembelajaran yang mendukung keberhasilan. Penentuan tersebut haruslah yang mampu menerapkan serta mengaplikasikan multi kriteria dan multi alternatif yang dihitung secara terstruktur dan memiliki tingkat kesalahan yang sangat kecil, adapun cara yang digunakan adalah dengan metode Analytic Hierarchy Process (AHP) yang ada dalam aplikasi software Super Decisions. Semua kriteria dan alternatif unggulan akan dibobot serta dirangking baik dengan tabel maupun dengan grafik. Hasil dari proses AHP adalah bobot final yang disertai dengan perangkingan kriteria dan alternatif sehingga menghasilkan alternatif (metode pembelajaran) terbaik yang mendapatkan bobot prioritas tertinggi. Alternatif yang memiliki bobot tertinggi digunakan sebagai bahan pendukung pengambilan keputusan bagi Dosen pengampu mata kuliah praktikum berbasiskan bahasa pemrograman komputer untuk diaplikasikan.
\end{abstract}

Kata kunci: Sistem Pendukung Keputusan (SPK), Analytical Hierarchy Process (AHP), Super Decisions, Bahasa Pemrograman, Kriteria, Alternatif, Metode Pembelajaran.

\section{PENDAHULUAN}

Metode pembelajaran yang digunakan pada hakekatnya adalah untuk keberhasilan pendidikan. Disamping metode pembelajaran yang tepat, keberhasilan pembelajaran juga dipengaruhi hal berikut ini, seperti : kemampuan Mahasiswa dalam menerima ilmu, komunikasi interaktif antara Dosen dan Mahasiswa serta faktor-faktor pendukung lainnya yang disiapkan dalam sistem pembelajaran.

Pada perkuliahan seperti praktikum komputer membutuhkan metode-metode tertentu untuk melatih, mengasah ketajaman analisa, pemahaman, perhitungan serta penerapan bahasa pemrograman komputer. Pelajaran praktikum berbasiskan bahasa pemrograman komputer adalah pelajaran terapan dari teoriteori yang telah diberikan untuk dilaksanakan di labor komputer. Sebelum praktikum dilakukan, terlebih dahulu dipersiapkan secara matang segala perangkat dan bahan ajar berupa modul maupun metode yang akan digunakan oleh dosen dalam perkuliahan praktikum tersebut.

Permasalahan yang ditemukan dalam praktikum yang berbasiskan bahasa pemrograman komputer selama ini, yaitu : (1) Mahasiswa kesulitan dalam pemahaman dan penerapan urutan-urutan kerja bahasa pemrograman. (2) Kurangnya antusias mahasiswa jika telah terbentur pada program yang error dan terkesan enggan 
mengulanginya atau tidak tahu apa lagi yang mesti dilakukan. (3) Kesulitan dalam memodifikasi skrip-skrip yang telah diberikan pada modul untuk penyelesaian masalah pada kasus yang sedikit dibedakan. (4) Kurang percaya diri untuk mengerjakan urutan-urutan seperti yang telah dibuatkan dalam modul jika kawan disebelahnya telah selesai sehingga mengurangi fokus dalam pemahaman modul tersebut (5) Terlalu cepat puas jika modul yang diselesaikan berhasil dieksekusi akan tetapi tidak memahami pertanyaan yang diberikan serta tidak mampu menarik kesimpulan terhadap proyek yang telah berhasil dieksekusi tersebut serta (6) Kurang mampu untuk berinovasi dengan membuat proyek yang baru dari penggabungan proyekproyek yang telah berhasil dieksekusinya.

Perkuliahan praktikum berbasiskan bahasa pemrograman komputer yang sudah dilengkapi dengan modul yang menjadi penuntun dalam memahami bahasa pemrograman komputer tidak semata-mata menjadikan keberhasilan bagi Mahasiswa untuk mambaca, memahami dan mempraktekkannya. Untuk itulah dibutuhkan kriteria-kriteria berupa cara-cara terbaik untuk mampu diterapkan secara tepat dan efektif dalam menunjang keberhasilan pembelajaran mata kuliah praktikum yang berbasiskan bahasa pemrograman komputer.

Misalnya, salah satu kriteria keberhasilan dalam praktikum tersebut adalah adanya media pembelajaran berbasis komputer, umumnya media pembelajaran yang terbaik adalah yang disukai oleh yang menerima pelajaran tersebut, karena dari kesukaannya terhadap sesuatu yang disampaikan maka sedikit banyaknya akan menyukai materimateri yang diajarkan seberapapun rumitnya.

\section{METODE AHP}

Kriteria-kriteria tersebut dihimpun serta dihitung kapabilitasnya untuk mampu dijadikan menjadi kriteria unggulan yang mendapatkan nilai tertinggi serta dijadikan sebagai bahan pertimbangan dalam pengambilan keputusan bagi dosen untuk diterapkan dalam pembelajaran praktikum komputer yang berbasiskan bahasa pemrograman komputer. Akan tetapi tentu saja media pembelajaran komputer bukan pula menjadi satu-satunya indikator keberhasilan tersebut.

Kriteria-kriteria unggulan dipilih dengan merangkingnya menggunakan perhitungan-perhitungan komputer yang terjamin keakuratannya. Perhitungan yang dimaksud adalah dengan penerapan metode Analytic Hierarchy Process (AHP), hal tersebut dikarenakan metode AHP mampu memproses penilaian terhadap banyak kriteria serta banyak alternatif yang menjadi ukuran dalam pencapaian sebuah tujuan, (R. Islam and Shuib, 2005).

Penerapan AHP digunakan secara efektif dalam pengambilan keputusan yang kompleks dan melibatkan pertimbangan faktor obyektif maupun subyektif, AHP menjadi alat yang berguna dalam penentuan faktor bobot, evaluasi serta memberikan dasar empiris untuk membantu dalam menetapkan keputusan yang terbaik, (Hemaida and Everett, 2003). Ada beberapa tahapan proses AHP yang dituangkan dalam Yang and Shi (2002), yaitu : menetapkan tujuan, mengidentifikasi semua kriteria yang relevan, membangun semua kriteria ke dalam sebuah struktur hirarki, membandingkan kriteria berdasarkan prioritas yang terjadi dengan matrik perbandingan berpasangan, menghitung bobot prioritas dan nilai kriteria, menganalisis dan mengevaluasi dampak dari semua kriteria dengan memeriksa konsistensi hirarkinya serta memasukkan nilai dari alternatif dengan menghitung bobot global yang diperoleh serta merangking metodemetode pembelajaran tersebut.

Melalui penerapan Analytic Hierarchy Process (AHP) akan mampu memberikan masukan terhadap pengambil keputusan dalam hal ini adalah Dosen pengampu mata kuliah praktikum yang berbasiskan bahasa pemrograman komputer untuk memilah, memilih, dan menerapkan media pembelajaran terbaik secara tepat dan

Metode AHP mampu memproses penilaian terhadap banyak kriteria yang 
menjadi ukuran dalam pencapaian sebuah tujuan, Islam [1]

Penerapan AHP digunakan secara efektif dalam proses pengambilan keputusan yang kompleks dan melibatkan pertimbangan faktor objektif maupun subjektif, AHP menjadi alat yang berguna dalam penentuan faktor bobot, evaluasi serta memberikan dasar empiris untuk membantu dosen dalam menetapkan keputusan yang terbaik.

Terdapat beberapa tahapan proses AHP Analytical Hierarchy Process (AHP) yang dituangkan dalam Yang and Shi [2], yaitu :

1. Menetapkan tujuan serta mengidentifikasi semua kriteria yang relevan.

2. Membangun semua kriteria ke dalam sebuah struktur hirarki.

3. Membandingkan kriteria berdasarkan prioritas dengan matrik perbandingan berpasangan.

4. Menghitung bobot prioritas dan nilai kriteria.

5. Menganalisis dan mengevaluasi dampak dari semua kriteria dengan memeriksa konsistensi hirarkinya.

6. Memasukkan nilai terhadap masingmasing kriteria yang diperoleh karyawan dengan menghitung bobot final serta merangkingnya.

Untuk perhitungan perbandingan matrik (pairewise comparisons) digunakan nilai dengan rentang 1-9, Palcic [4] seperti berikut ini :

\begin{tabular}{|c|l|}
\hline Value & \multicolumn{1}{|c|}{ Description of comparison } \\
\hline 1 & Equality \\
\hline 3 & Somewhat greater importance of one criterion over another \\
\hline 5 & Strong superiority of one criterion over another \\
\hline 7 & Very strong superiority of one criterion over another (clearly seen in practice) \\
\hline 9 & Absolute (highest possible) superiority of one criterion over another \\
\hline \multicolumn{2}{|c|}{ Note: use of values in between $(2,4,6,8)$ is permitted. } \\
\hline
\end{tabular}

Gambar 2. Nilai Perbandingan Matrik dalam AHP

\subsection{Menetapkan Tujuan}

Tujuan yang ditetapkan pada tulisan ini adalah pemilihan metode pembelajaran praktikum berbasiskan bahasa pemrograman komputer.

\subsection{Menetapkan Kriteria}

Adapun kriteria yang digunakan untuk pemilihan metode pembelajaran pada praktikum berbasiskan bahasa pemrograman komputer yaitu, sebagaimana gambar berikut ini :

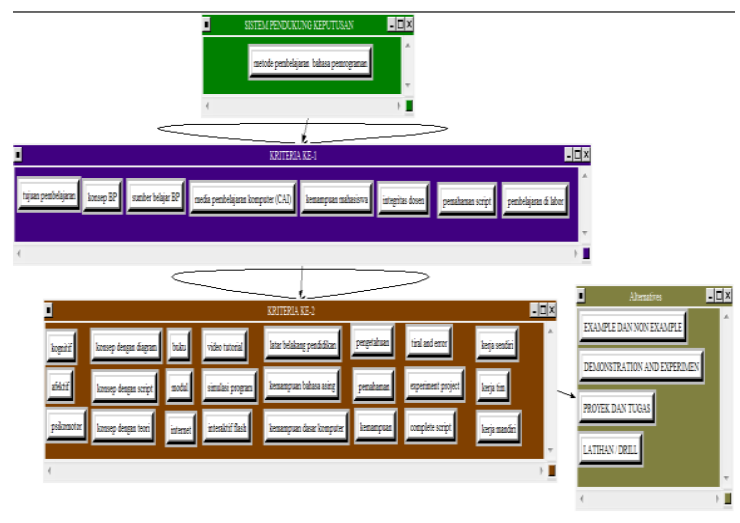

Gambar 1. Susunan Hirarki AHP Kriteria Unggulan Pemilihan Metode Pembelajaran

Kriteria yang ditetapkan didapatkan dari hasil penelitian baik itu penelitian di lapangan, wawancara langsung, maupun pengumpulan data. Langkah selanjutnya adalah menetapkan bobot kriteria dengan membuatkan matrik berpasangan antar kriteria tersebut. Pada kriteria utama, terdapat kriteria : integritas Dosen (K1), kemampuan Mahasiswa (K2), konsep bahasa pemrograman (3), media komputer (4), pemahaman skrip (5), pembelajaran di labor (6), sumber belajar (7), tujuan belajar (8).

Selanjutnya data ditabulasi dengan mendapatkan nilai rata-rata dari kesemua responden yang berjumlah 80 orang responden. Rata-rata yang didapatkan selanjutnya dimasukkan ke dalam matrik berpasangan, yang digunakan untuk perkalian matrik dengan ordo nxn.

Matrik berpasangan tersebut dibuatkan seperti berikut ini :

\begin{tabular}{|c|c|c|c|c|c|c|c|}
\hline ID & KM & KBP & MK & PS & PL & SB & TP \\
\hline $\mathbb{D}$ & 0.825074 & 1.540997 & 3.514271 & 3.89583333 & 3.598785 & 4.137674 & 3.775 \\
\hline KM & & 3.775 & 3.407361 & 3.48767361 & 3.893403 & 4.147222 & 3.748611 \\
\hline KBP & & & 3.794444 & 3.40736111 & 3.487674 & 3.893403 & 3.748611 \\
\hline MK & & & & 3.79444444 & 6.376389 & 4.125 & 3.861111 \\
\hline PS & & & & & 3.961111 & 4.441667 & 4.293056 \\
\hline PL & & & & & & 4.818056 & 4.590278 \\
\hline SB & & & & & & & 4.375 \\
\hline TP & & & & & & & \\
\hline
\end{tabular}


Penelitian Bidang Komputer Sains dan Pendidikan Informatika V1.i1(23-29)

\section{Gambar 2. Matrik Berpasangan} Kriteria Utama

Selanjutnya dibuatkan perkalian matrik dengan ordo sama $\mathrm{n} \times \mathrm{n}$, sehingga didapatkan bobot dari masing-masing kriteria tersebut.

\section{Menetapkan Nilai (Bobot) Kriteria}

Adapun bobot kriteria diperoleh dari hasil perkalian matrik sebagaimana yang telah diperlihatkan pada tabel 1. Perkalian matrik bisa dilakukan hingga 3 (tiga) iterasi. Untuk bobot dari masing-masing kriteria diperoleh sebagaimana tabel berikut ini :

Tabel 1. Bobot Kriteria Utama

\begin{tabular}{|l|rc|}
\hline Kriteria Ke-1 & \multicolumn{1}{c}{ Bobot } & Rank \\
\hline Kemampuan Mahasiswa & 0.25112 & 1 \\
Integritas Dosen & 0.20963 & 2 \\
Konsep Bahasa & & \\
Pemrograman & 0.17509 & 3 \\
Media Komputer & 0.138281 & 4 \\
Pemahaman Script & 0.088702 & 5 \\
Pembelajaran Di Labor & 0.063006 & 6 \\
Sumber Belajar & 0.040441 & 7 \\
Tujuan Pembelajaran & 0.028865 & 8 \\
\hline
\end{tabular}

Dengan cara yang sama, bobot dari kriteria level 2 dapat ditentukan, sebagaimana berikut ini :

Tabel 2. Bobot Sub Kriteria

\begin{tabular}{|l|ll|}
\hline Kriteria Ke-2 & Bobot & Rank \\
\hline trial and error & 0.531517 & 1 \\
pengetahuan & 0.492248 & 2 \\
kognitif & 0.454312 & 3 \\
konsep dg script & 0.409807 & 4 \\
Latar belakang pddkn & 0.395326 & 5 \\
kerja mandiri & 0.391918 & 6 \\
video tutorial & 0.368656 & 7 \\
afektif & 0.365259 & 8 \\
internet & 0.357445 & 9 \\
interaksi flash & 0.346886 & 10 \\
modul & 0.346632 & 11 \\
\hline
\end{tabular}

\begin{tabular}{|l} 
Kemampuan bhs asing \\
konsep dg diagram \\
kerja sendiri \\
kerja tim \\
buku \\
kemampuan \\
simulasi program \\
Kemampuan dasar \\
komputer \\
complete script \\
konsep dg teori \\
pemahaman \\
exsperiment project \\
psikomotor
\end{tabular}

\begin{tabular}{|ll|}
\hline 0.340564 & 12 \\
0.334275 & 13 \\
0.310037 & 14 \\
0.298045 & 15 \\
0.295923 & 16 \\
0.289953 & 17 \\
0.284458 & 18 \\
& \\
0.264111 & 19 \\
0.259124 & 20 \\
0.255918 & 21 \\
0.217799 & 22 \\
0.209359 & 23 \\
0.180429 & 24 \\
\hline
\end{tabular}

Matrik harus diuji nilai inconsistency atau tingkat kesalahan matrik, sebagaimana berikut ini :

Nilai consistency index $\mathbf{C I}=($ Emaks-n $) /(\mathbf{n}-\mathbf{1})$

(1)

Keterangan :

$\mathrm{n}=$ ordo matrik

Nilai consistency ratio atau inconsistency index adalah :

$\mathbf{C R}=\mathbf{C I} / \mathbf{R C I}$

Tabel 3. Nilai RCI berdasarkan ordo matrik, Avangelos [3].

\begin{tabular}{|lllllll|}
\hline $\mathbf{n}$ & $\mathbf{1}$ & $\mathbf{2}$ & $\mathbf{3}$ & $\mathbf{4}$ & $\mathbf{5}$ & $\mathbf{6}$ \\
$\mathrm{RCI}$ & 0 & 0 & 0.58 & 0.9 & 1.12 & 1.2 \\
& & & & & & 4 \\
\hline
\end{tabular}

Jika nilai $\mathrm{CR}<10 \%$ maka nilai set matrik perbandingan adalah konsisten dan perhitungan dapat untuk terus dilanjutkan, namun jika nilai CR > 10\% maka kesalahan terhadap nilai yang dibandingkan terlalu tinggi dan nilai set matrik perbandingan perlu untuk diset ulang (Saaty, 1980)

Dengan nilai $C R=0.1043$ untuk matrik kriteria utama, serta nilai $\mathrm{CR}=0.0444$ untuk matrik level ke-2, hal tersebut berarti nilai CR kecil dari $10 \%$ maka perhitungan matrik dianggap konsisten dan bisa untuk dilanjutkan kepada tahap berikutnya. 


\section{Menetapkan Nilai Matrik Alternatif}

Nilai matrik alternatif juga diambil dari data kuisioner. Nilai matrik alternatif didapatkan dengan membandingkan antar alternatif sesuai dengan kriterianya masingmasing. diperlihatkan sebagaimana berikut ini

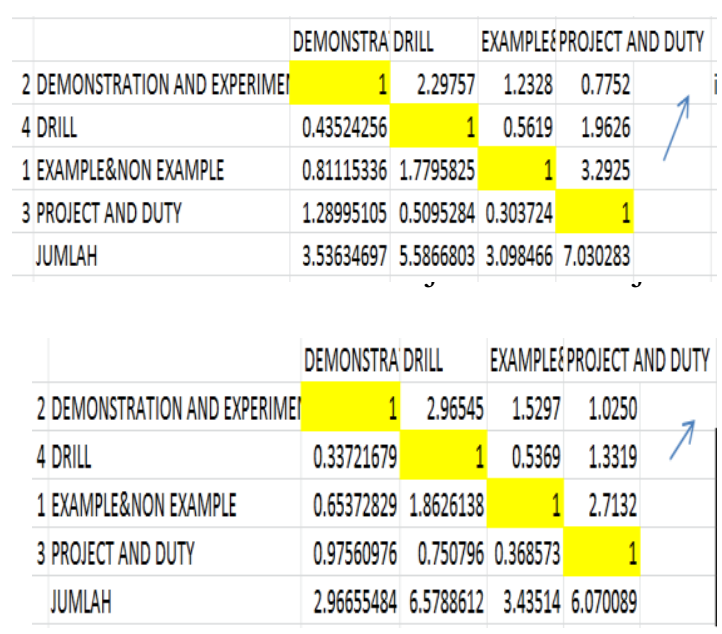

Gambar 4. Tabulasi Nilai Matrik Pada

Kriteria Konsep Bahasa Pemrograman

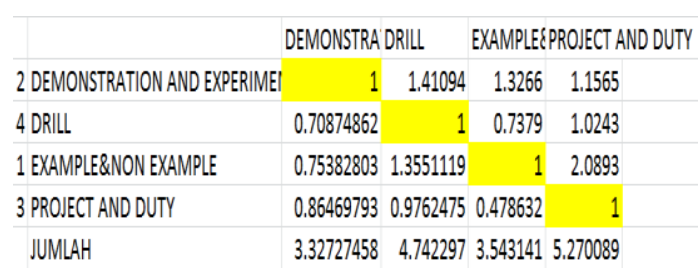

Gambar 5 Tabulasi Nilai Matrik Pada Kriteria

Sumber Belajar Bahasa Pemrograman

\begin{tabular}{l|rrrr}
\hline & DEMONSTRA DRILL & EXAMPLEEPROJECT AND DUTY \\
\hline 2 DEMONSTRATION AND EXPERIMEI & 1 & 0.98125 & 0.9797 & 1.1328 \\
\hline 4 DRILL & 1.01910828 & 1 & 4.0172 & 3.2875 \\
\hline 1 EXAMPLE\&NON EXAMPIE & 1.02073365 & 0.2489304 & 1 & 3.1783 \\
\hline 3 PROJECT AND DUTY & 0.88275862 & 0.3041825 & 0.314629 & 1 \\
\hline JUMLAH & 3.92260055 & 2.5343629 & 6.311504 & 8.598661 \\
\hline
\end{tabular}

Gambar 6. Tabulasi Nilai Matrik Pada Kriteria Media Pembelajaran Komputer

\begin{tabular}{l|rrrr} 
& \multicolumn{2}{c}{ DEMONSTRA DRILL } & EXAMPLEEPROJECT AND DUTY \\
\hline 2 DEMONSTRATION AND EXPERIMEI & 1 & 1.31563 & 0.9000 & 2.4875 \\
\hline 4 DRILL & 0.76009501 & 1 & 3.7531 & 2.5813 \\
\hline 1 EXAMPLE\&NON EXAMPLE & 1.11111111 & 0.2664446 & 1 & 2.7781 \\
\hline 3 PROJECT AND DUTY & 0.40201005 & 0.3874092 & 0.359955 & 1 \\
\hline JUMLAH & 3.27321617 & 2.9694788 & 6.01308 & 8.846875 \\
\hline
\end{tabular}

Gambar 7. Tabulasi Nilai Matrik Pada Kriteria Kemampuan Mahasiswa

\begin{tabular}{l|rrrr} 
& \multicolumn{1}{c}{ DEMONSTRA DRILL } & \multicolumn{3}{c}{ EXAMPLEEPROJECT AND DUTY } \\
\hline 2 DEMONSTRATION AND EXPERIMEI & 1 & 2.02917 & 0.9469 & 0.5547 \\
\hline 4 DRILL & 0.49281314 & 1 & 0.1742 & 1.2983 \\
\hline 1 EXAMPLE\&NON EXAMPLE & 1.05610561 & 5.7419539 & 1 & 1.1623 \\
\hline 3 PROJECT AND DUTY & 1.8028169 & 0.7702594 & 0.860038 & 1 \\
\hline JUMLAH & 4.35173565 & 9.54138 & 2.981412 & 4.015228 \\
\hline
\end{tabular}

Gambar 8. Tabulasi Nilai Matrik Pada Kriteria Integritas Dosen

\begin{tabular}{|c|c|c|c|}
\hline & \multicolumn{3}{|c|}{ DEMONSTRA DRILL $\quad$ EXAMPLESPROJECT AND DUTY } \\
\hline 2 DEMONSTRATION AND EXPERIMEI & 11.60399 & 0.9938 & 1.4016 \\
\hline 4 DRILL. & 0.6234441 & 1.3909 & 1.9528 \\
\hline 1 EXAMPLE\&NON EXAMPLE & 1.006289310 .7189601 & 1 & 1.9676 \\
\hline 3 PROJECT AND DUTY & $0.71348941 \quad 0.512091$ & 0.508225 & 1 \\
\hline JUMLAH & 3.3432222813 .8350442 & 3,892872 & 6.321974 \\
\hline
\end{tabular}

Gambar 9. Tabulasi Nilai Matrik Pada Kriteria Pemahaman Skrip

\begin{tabular}{l|rrrr|} 
& \multicolumn{3}{c}{ DEMONSTRA DRILL } & \multicolumn{3}{c}{ EXAMPLEPPOJECT AND DUTY } \\
\hline 2 DEMONSTRATION AND EXPERIMEI & 1 & 1.20156 & 1.0266 & 2.7125 \\
\hline 4 DRILL & 0.832249667 & 1 & 3.7301 & 2.4719 \\
\hline 1 EXAMPIE\&NON EXAMPIE & 0.97412481 & 0.2680869 & 1 & 2.7297 \\
\hline 3 PROJECT AND DUTY & 0.36866359 & 0.4045512 & 0.366342 & 1 \\
\hline JUMLAH & 3.17503808 & 2.8742006 & 6.123039 & 8.9140663
\end{tabular}

Gambar 10. Tabulasi Nilai Matrik Pada Kriteria Pembelajaran di Labor

Untuk pengolahan hasil dibutuhkan software Super Decisions dimana nilai tabulasi tersebut dimasukkan untuk mendapatkan : (1) Bobot kriteria utama dan level 2, (2) Bobot alternatif untuk masingmasing kriteria, (3) Perangkingan kriteria dan alternatif.

\section{HASIL DAN PEMBAHASAN}

\section{Penentuan Bobot Kriteria dengan Super Decisions}

Dengan menggunakan software AHP Super Decisions dapat dicari hasil berupa 


\section{Jurnal Edik Informatika}

bobot kriteria dan alternatif pada masingmasing kriteria sebagaimana berikut ini :

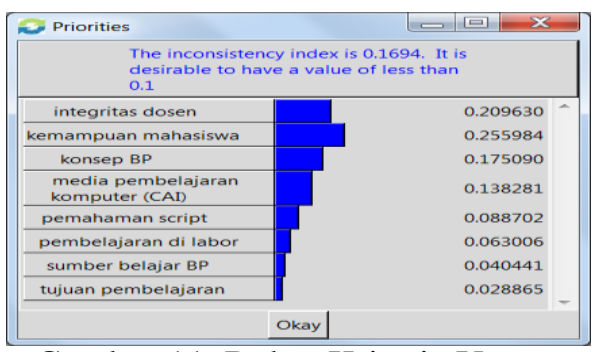

Gambar 11. Bobot Kriteria Utama

Nilai yang telah ditabulasi diinputkan ke dalam software Super Decisions,

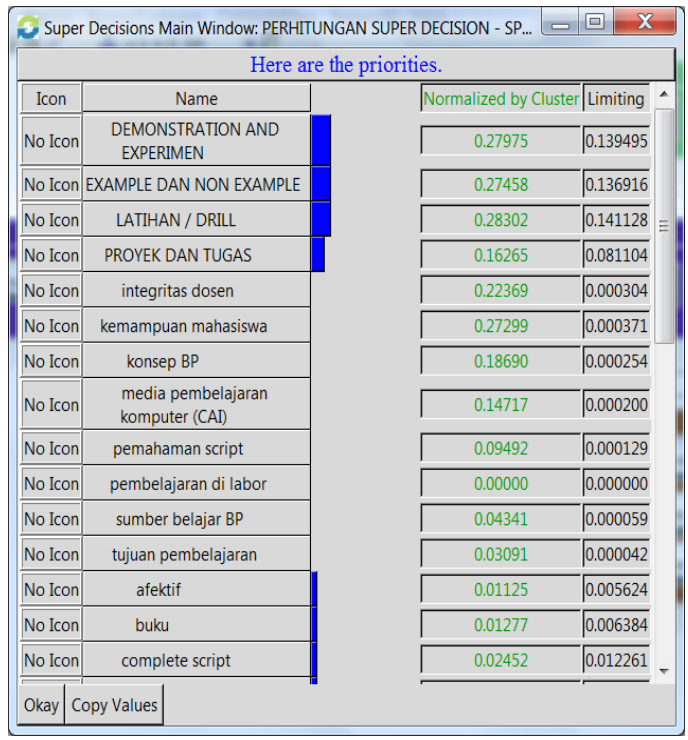

Gambar 12. Bobot Masing-masing Kriteria (Utama dan Level ke-2)

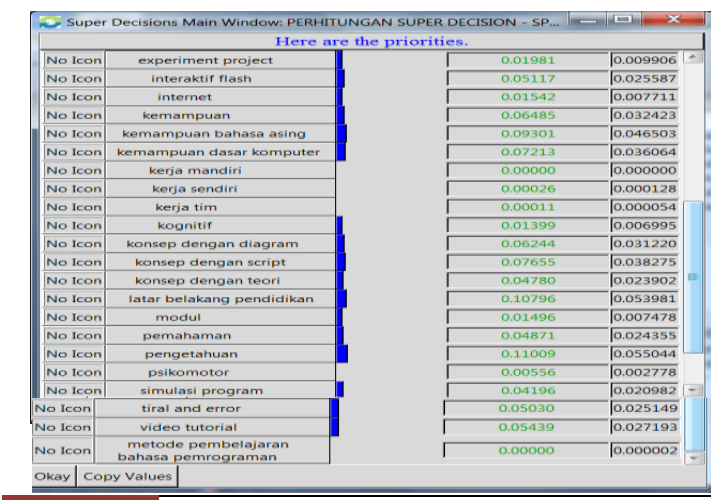

Gambar 13. Bobot Masing-masing Kriteria (Utama dan Level ke-2)

\subsection{Penentuan Bobot Alternatif dengan Super Decisions}

Hasil perhitungan final (bobot final) yang diperoleh masing-masing karyawan yang mana sudah dikalkulasikan dengan semua kriteria, diperlihatkan pada gambar berikut ini

\section{Report for toplevel}

This is a report for how alternatives fed up through the system to give us our synthesized values. Ret Alternative Rankings

\begin{tabular}{||c||c||c|c|c|c|}
\hline \hline Graphic & Alternatives & Total & Normal & Ideal & Ranking \\
\hline \hline & DEMONSTRATION AND EXPERIMEN & 0.1395 & 0.2797 & 0.9884 & 2 \\
\hline \hline & EXAMPLE DAN NON EXAMPLE & 0.1369 & 0.2746 & 0.9702 & 3 \\
\hline \hline & LATIHAN / DRILL & 0.1411 & 0.2830 & 1.0000 & 1 \\
\hline \hline & PROYEK DAN TUGAS & 0.0811 & 0.1626 & 0.5747 & 4 \\
\hline \hline
\end{tabular}

Gambar 14. Hasil Final Bobot Alternatif Pada Super Decisions

Dari hasil perangkingan terhadap bobot prioritas yang didapatkan, maka dapat diambil kesimpulan bahwa 'Latihan dan Drill' memiliki bobot tertinggi disusul dengan 'Demostration and Experiment' dan 'Example dan Non Example'.

Metode pembelajaran 'Latihan dan Drill' mendapatkan rangking tertinggi, sebagai bahan untuk pengambilan keputusan bagi Dosen untuk menerapkan metode pembelajaran terbaik dan paling efektif adalah dengan memberikan latihan secara intensif disertai dengan teknik modifikasi skrip yang setengah jadi ke skrip yang komplit, tentunya akan menambah minat dalam mempelajari bahasa pemrograman komputer melalui cara tersebut.

\section{KESIMPULAN}


Penelitian Bidang Komputer Sains dan Pendidikan Informatika V1.i1(23-29)

1. Metode AHP digunakan untuk perhitungan multi kriteria dan multi alternatif yang dikalkulasikan menggunakan software Super Decisions.

2. Dengan menggunakan metode AHP, data telah diolah melalui proses komputerisasi serta menghasilkan perhitungan yang cepat dan tepat dan objektif serta nilai inconsistency yang rendah pada setiap pembahasan pada tabel menunjukkan bahwa matrik yang diperbandingkan adalah ideal dengan tingkat kesalahan rendah serta mampu dijadikan bahan sebagai pendukung keputusan bagi para pengambil keputusan.

3. Dengan menerapkan metode AHP pada SPK pemilihan metode pembelajaran berbasis bahasa pemrograman komputer, yang diterapkan melalui proses dengan aplikasi Super Decisions mendapatkan metode 'latihan dan drill' merupakan pilihan utama dalam pembelajaran tersebut

4. Metode latihan dan drill dipilih dan digunakan secara intensif dengan membuatkan bahan ajar yang berupa latihan dan drill beserta silabus, RPKPS, modul, handout yang berbasiskan latihanlatihan intensif dengan proyek-proyek ringan hingga sedang yang bisa dimodifikasi yang didasarkan kepada latihan dan drill secara intensif dan praktis dengan simulasi-simulasi, proyek setengah jadi untuk disempurnakan serta menjadikan proyek karya Mahasiswa sebagai modal untuk berwiraswasta bagi mereka sebagai penambah semangat dalam memupuk minat dan bakat dalam belajar bahasa pemrograman komputer.

\section{PUSTAKA}

Islam, Rafikul. Shuib. Employe Performasnce Evaluation By AHP : A Case Study. dlSAHP, Honolulu, Hawaii, 2005.

Jiaqin Yang, Ping Shi. Applying Analitic Hierarchy Process in Firm's Overall Performance Evaluation : A Case Study in China, international journal of business 7 (1), ISSN : 1083-4346, 2002.

Avangelos, Stuart. Using the Hierarchy Processfor Decision Makingin Enginering Applications:Some Challange.International Journal of Industrial Engineering, vol.2 No.1, pp. 35-44.

Palcic, I. and Lalic. B. Analitcal Hierarchy Process As a Tool for Selecting and Evaluating Project. Original scientific paper, model 8, 16-26, ISSN :17264529, 2009 (1).

Bhattacharya, Subramanian J, Bhopte B. Implementation of Analytical Hierarchical Process to support decisions in Employee Performance Appraisal. International Journal of Computer Science and Information Technology and Security (IJCSITS), vol.2, no.2, ISSN :2249-9555, 2012.

Anagnostopoulos, Vavatsicos. An AHP Model for Contruction Contractor Prequalification International Journal, Vol 6, pp.333-346, 2006.

Paul, Thomas. Examining of Implications of Process and Choice for StrategicDecisions Making Effectiveness, Vol 2, No.3, 2010. 